\title{
Management Coaching Model and Impact of its Activities on Employee Satisfaction
}

\author{
PETRA CAJNKO \& SUZANA KRALJić
}

\begin{abstract}
The article tries to answer the research question: What is the potential additive effect on employee satisfaction when using management coaching model and its activities? The purpose of the article has been to form a model of management coaching and of the influence of its activities on employee satisfaction based on theory review and field study results. We have confirmed the main hypothesis (H1: Implementing management coaching model positively influences employee satisfaction) and all of the secondary hypotheses (Hi,j: Implementing activity $» \dot{i} \ll$ of the management coaching model positively influences factor $» j$ « of employee satisfaction; $i=1,2,3,4$, $5 ; \mathrm{j}=1,2,3,4,5)$ with our empirical study, focused on the employees. The topic is of practical value and it will help managers in Slovenia and abroad understand the effect of the activities of coaching on employee satisfaction.
\end{abstract}

Keywords: • coaching $\bullet$ satisfaction of employees $\bullet$ successfulness of an enterprise $\cdot$ management $\bullet$ model $\bullet$

CorRespondence AdDress: Petra Cajnko, PhD, Society of Insured Persons Slovenia, Trg svobode 3, 2000 Maribor, Slovenia, e-mail: dr.petra.cajnko@gmail.com. Suzana Kraljić, $\mathrm{PhD}$, Associate Professor, University of Maribor, Faculty of Law, Mladinska ulica 9, 2000 Maribor, Slovenia, e-mail: suzana.kraljic@um.si.

UDC: $65.011 .8: 658.310 .8$ 
$134 \mid \begin{aligned} & \text { LEXONOMICA } \\ & \text { P. Cajnko \& S. Kraljić: Management Coaching Model and Impact of its Activities on Employee } \\ & \text { Satisfaction }\end{aligned}$

\section{$1 \quad$ Introduction}

Economy plays a vital part in a functioning country. The state of economy has been very unstable in the past few years. It has become increasingly difficult to accomplish the stated objectives. But this crisis does provide an excellent opportunity for improving enterprise performance (Cajnko, 2014: 1).

Investing in human capital is nowadays the most lucrative and also the safest way of investing - the human capital can be endlessly ennobled, its value can only increase and, most importantly, it is the only form of capital that cannot be stolen (Mihalič, 2006: 1). People, therefore, are becoming more and more important in the company; managers and employees alike represent the company«s advantage over other companies. It is important that employees feel well, motivated and satisfied when doing their job. Of equal importance is manager «s correct usage of his or hers management skills as it influences employee satisfaction.

We see the originality of our paper in the fact, that the findings of our study will enable employees and individuals to familiarize themselves with a number of methods and models that help bring coaching activities closer to individuals and in that way improve general satisfaction as well as workplace satisfaction.

Implementing coaching activities in a company represents one of the possibilities for emergence from the crisis the economy is in at the moment. Manager who is a coach can be socially responsible toward his employees, the company and the society in general as well as the environment; that is a basis for existence of countries and the world.

\section{Theoretical framework}

\subsection{Management aspect of employee satisfaction}

Employee satisfaction is a complex concept; it demands knowledge and various skills for its interpretation. It is the sum of partial (dis)satisfactions that sway one way or the other. Authors have different definitions of employee workplace satisfaction (George and Jones, 1996: 70; Hollenbeck and Wright, 1994: 176; Cahill, 1996: 164; Maister, 2003: 272; Oakley, 2004: 15; Topolsky, 2000: 128). Management aspect of employee satisfaction forms one of the basic constructs in our study (constructs in the coaching framework and the employee satisfaction construct).

Every manager who wants to pride himself with his business achievements knows that satisfied employees are a key prerequisite. A manager and a company is only as strong as the human capital in it.

Numerous studies (Pohlmann, 1999; Oswald and Clark, 1996; Desmarais, 2005; Parent-Thirion et al., 2007; Škerlavaj et al., 2007) have been carried out in order to determine the factors that influence employee satisfaction. People are different: what 
one may perceive as satisfactory the other perceives as dissatisfactory. Lawler (1994: 83) states that there is an infinite number of factors that influence employee satisfaction, just as there is an infinite number of needs.

The most renown and influential study on employee satisfaction and motivation was carried out by Gallup Institute (Slovenian Human Resource Association, 2014). In the study they classify the employees « motivation in three categories: motivated (work with passion, feel deep connection with the organization, encourage innovation), unmotivated (work solely for the paycheck, they only contribute their time without their energy and passion) and actively unmotivated (not only unsatisfied but actively expressing it, undermining motivated coworkers). The latest Gallup Institute study (Slovenian Human Resource Association, 2014). found that, globaly (142 countries participated), only every eighth employee (13\%) is motivated, $63 \%$ are unmotivated and $24 \%$ are actively unmotivated. The results for Slovenia were as follows: $15 \%$ motivated, $70 \%$ unmotivated and $15 \%$ actively unmotivated. That means that there is a great internal potential for improving business performance on the level of individuals, companies and the economy as a whole. ${ }^{1}$

Our study focused on management aspects of employee satisfaction. Based on that and the theoretical framework describing measurement of employee satisfaction, we define the following factors of employee satisfaction: (i) job content. (ii) individual creativity, (iii) salary, extras and benefits, (iv) organization of work, (v) teamwork, (vi) working conditions, (vii) independence at work, (viii) job stability and safety, safety at the workplace, (ix) relationships, (x) possibility for training and education, (xi) ownership participation, (xii) communication, (xiii) personality, and (xiv) societal influences. We used the stated factors for measuring employee satisfaction. We used established measurement scales in the available literature (Porter and Steers, 1973; Brayfield and Rothe, 1951; Cammann el al., 1983; Wiess et al., 1967) and modified them to fit our study.

\subsection{Management coaching}

In recent years, many companies (and especially managers) in the United Kingdom and Western Europe have started studying and implementing coaching in order to contribute to: (i) personal and professional development of the employees, (ii) building of pleasant relationships, (iii) building of career, (iv) managing the business, (v) planning the development, (vi) setting of strategic objectives, (vii) setting of business plans, (viii) building of values, and, last but not least, (ix) employee workplace satisfaction.

The word »coach« originates in the French word »coche«, which means a carriage. In the past »coaching « was used to describe travelling with a carriage. »A coach« is therefore a vehicle that drives an individual or a group »from a starting point to a suggested goal« (Stemberger, 2008).

\footnotetext{
${ }^{1}$ Slovenian Human Resource Association, 2014.
} 
$136 \mid$\begin{tabular}{l|l} 
LEXONOMICA \\
P. Cajnko \& S. Kraljić: Management Coaching Model and Impact of its Activities on Employee \\
Satisfaction
\end{tabular}

There are various definitions of management coaching (Čeč, 2006; Megginson and Clutterbuck, 2007; Lehinsky, 2007; Stemberger, 2008). We could say there are as many definitions of coaching as there are schools for it. Stemberger (2008) claims that the key element that differs coaching from other disciplines that help individual employees and companies to evolve, is the manager - coach - that helps each individual and company to find an independent solution that leads in the right direction. The manager does not consult on the best path, but instead helps employees get there on their own.

Skiffington and Zeus (2003) define coaching as a conversation that takes place in a objective oriented and productive context. Coaching enables an individual to access his knowledge; he could have the answer in the palm of his hand but have never considered it.

Coaching is often viewed as a strategic investment in human capital - a perk reserved for employees with high potential - and managers have realized that they need to participate in the process (Dattner, 2014).

Management coaching, in our conviction, is a process in which coaching has to become a way of private as well as professional life. A coach has to see the potential in his employees, see what they can evolve in to. A coach «s key mission is guiding employees so they can take advantage of their hidden talents and skills and creating an atmosphere that drives employees to evolve into better and more successful people.

Coach treats an individual as a whole. He believes other aspects of employee «s life influence his workplace decisions. Decisions about professional career also influence family, health and friends (Whitworth et al., 2011).

Various authors (Stokes, 2008; Jarvis, 2006; Goffee, 2006; Hall, 2006) cited numerous advantages and benefits of management coaching: (i) progress in mission, (ii) progress in activity reflection, (iii) increased self-awareness and awareness of consequences of actions, (iv) progress in balanced decision making when multitasking, and, (v) progress in communication.

Our study defines management coaching as a method that provides support and opportunity for consulting individual employees as well as entire staff by managers - coaches - so that individual employees and entire staff become aware of the way to workplace satisfaction.

Determining activities that are the foundation for measurements of effectiveness of coaching is of key importance; it is the only way to bring focus to actions that can bring desired effects and results.

Based on definition and theoretical foundation for measuring management coaching we defined the following activities (constructs) of management coaching: (i) 
empathy, (ii) assertive communication, (iii) decision making ability, (iv) strategic thinking, (v) delegation, (vi) work optimization, (vii) broadening of horizon, (viii) conflict resolution, (ix) effective meeting conduction, (x) improved public appearance skills, and (xi) increased employee «s commitment to the company. We used the stated activities to measure management coaching effectiveness. We used established measuring instruments and scales (Spector, 1997; Gounaris, 2006; Možina, 1992; Cornelius and Hakel, 1978; Porter and Steers, 1973) for measuring management coaching effectiveness and modified them to study the effect of management coaching.

The objective of our study was to design a model of management coaching and of the influence of its activities on employee satisfaction based on theory review and our field research. We based our management coaching model on the following activities: (i) empathy, (ii) assertive communication, (iii) strategic thinking, (iv) delegation and (v) work optimization. The basis of our management coaching model is also formed by the following factors of employee satisfaction: (i) job content, (ii) individual creativity, (iii) organization of work, (iv) teamwork and (v) relationships. The stated activities and factors were chosen after careful consideration, taking into account the convenience of the measuring instrument: it would have been difficult to achieve a good response rate with a more extensive questionnaire.

Thein depth review of the literature on the topic of coaching, employee satisfaction and their interconnections and influences was followed by an empirical study of management aspect of influence of coaching activities on employee satisfaction on a sample of Slovenian companies.

\section{$3 \quad$ Methodology}

Here we describe empirical testing of the managerial coaching model and the hypotheses that we had posed. The empirical starting point was designing measuring instruments (for employees) and compiling a sample of companies in Slovenia with more than ten employees. The study is based on the theoretical foundation, managerial coaching model, research methodology, and on the thesis, the one main hypothes and the secondary hypotheses $\mathrm{H}_{\mathrm{i}, \mathrm{j}}(\mathrm{i}=1,2,3,4,5 ; \mathrm{j}=1,2,3,4,5)$.

The paper deals with human resources management. We used the available literature and our empirical study to try to answer the fundamental research question: What is the potential added effect of using the management coaching model and its activities on employee satisfaction?

\subsection{Fundamental thesis}

The thesis tries to answer the research question. It states:

T: Companies can, with some care put into implementing components of management coaching model, significantly influence employee satisfaction. 
138 |l $\begin{aligned} & \text { LEXONOMICA } \\ & \text { P. Cajnko \& S. Kraljić: Management Coaching Model and Impact of its Activities on Employee } \\ & \text { Satisfaction }\end{aligned}$

To confirm the thesis we tested the following hypothesis:

$\mathbf{H}_{1}$ : Implementing management coaching model positively influences employee satisfaction.

We tested the correlation among the constructs of coaching and the individual components of employee satisfaction:

$\mathbf{H}_{\mathrm{i}, \mathrm{j}}$ : Implementing activity $» \mathbf{I} \ll$ of the management coaching model positively influences factor $\gg j \ll$ of the employee satisfaction.

$\mathrm{i}=1,2 \ldots, 5 ; \mathrm{j}=1,2 \ldots, 5$

Below we state all the $\mathrm{H}_{\mathrm{i}, \mathrm{j}}$ hypotheses we tested in order to confirm the main hypothesis and, consequently, the thesis.

(coaching construct influences employee satisfaction)

$\mathrm{H}_{11}$ : Empathy positively influences employee satisfaction.

$\mathrm{H}_{21}$ : Assertive communication positively influences employee satisfaction.

$\mathrm{H}_{31}$ : Strategic thinking positively influences employee satisfaction.

$\mathrm{H}_{41}$ : Delegation positively influences employee satisfaction.

$\mathrm{H}_{51}$ : Work optimization positively influences employee satisfaction.

( $1^{\text {st }}$ coaching construct - empathy - influences employee satisfaction)

$\mathrm{H}_{11 \mathrm{a}}$ : Empathy positively influences relationships.

$\mathrm{H}_{12 \mathrm{~b}}$ : Empathy positively influences individual creativity.

$\mathrm{H}_{13 \mathrm{c}}$ : Empathy positively influences job content.

$\mathrm{H}_{14 \mathrm{~d}}$ : Empathy positively influences teamwork.

$\mathrm{H}_{15 \mathrm{e}}$ : Empathy positively influences organization of work.

$\left(2^{\text {nd }}\right.$ coaching construct - assertive communication - influences employee satisfaction)

$\mathrm{H}_{21 \mathrm{a}}$ : Assertive communication positively influences relationships.

$\mathrm{H}_{22 \mathrm{~b}}$ : Assertive communication positively influences individual creativity.

$\mathrm{H}_{23 \mathrm{c}}$ : Assertive communication positively influences job content.

$\mathrm{H}_{24 \mathrm{~d}}$ : Assertive communication positively influences teamwork.

$\mathrm{H}_{25 \mathrm{e}}$ : Assertive communication positively influences organization of work.

( $3^{\text {rd }}$ coaching construct - strategic thinking - influences employee satisfaction)

$\mathrm{H}_{31 \mathrm{a}}$ : Strategic thinking positively influences relationships.

$\mathrm{H}_{32 \mathrm{~b}}$ : Strategic thinking positively influences individual creativity.

$\mathrm{H}_{33 \mathrm{c}}$ : Strategic thinking positively influences job content.

$\mathrm{H}_{34 \mathrm{~d}}$ : Strategic thinking positively influences teamwork.

$\mathrm{H}_{35 \mathrm{e}}$ : Strategic thinking positively influences organization of work.

( $4^{\text {th }}$ coaching construct - delegation - influences employee satisfaction $)$

$\mathrm{H}_{41 \mathrm{a}}$ : Delegation positively influences relationships. 
$\mathrm{H}_{42 \mathrm{~b}}$ : Delegation positively influences individual creativity.

$\mathrm{H}_{43 c}$ : Delegation positively influences job content.

$\mathrm{H}_{44 \mathrm{~d}}$ : Delegation positively influences teamwork.

$\mathrm{H}_{45 \mathrm{e}}$ : Delegation positively influences organization of work.

( $5^{\text {th }}$ coaching construct - work optimization - influences employee satisfaction)

$\mathrm{H}_{51 \mathrm{a}}$ : Work optimization positively influences relationships.

$\mathrm{H}_{52 \mathrm{~b}}$ : Work optimization positively influences individual creativity.

$\mathrm{H}_{53 \mathrm{c}}$ : Work optimization positively influences job content.

$\mathrm{H}_{54 \mathrm{~d}}$ : Work optimization positively influences teamwork.

$\mathrm{H}_{55}$ e: Work optimization positively influences organization of work.

As stated, we tested for the correlation among: (i) the coaching constructs and the employee satisfaction construct $\left(\mathrm{H}_{11}\right.$ through $\left.\mathrm{H}_{51}\right)$, and (ii) the coaching constructs and individual components of employee satisfaction $\left(\mathrm{H}_{11 \mathrm{a}}\right.$ through $\left.\mathrm{H}_{55 \mathrm{e}}\right)$.

\subsection{Preliminary study}

Below we present our preliminary study. We had to test the contextual validity of our polling questionnaire, so we performed a preliminary quantitative study. We used the questionnaire on a sample of bank tellers in Slovenia ${ }^{2}$. The questionnaire was based on the questionnaire we later used on employees.

Respondents were 48 bank tellers from 18 different branch offices of banks in Slovenia. Filling in the questionnaire took about 12 minutes. Polling took place in January and February of 2014.

With the preliminary quantitative analysis we determined which statements best describe the influence of coaching activities on factors of employee satisfaction. It helped us see how the respondents understand individual constructs and their components. We saw they had problems understanding the construct of assertive communication, so we rewrote the statements and reduced their number from 9 to 7 .

Having tested the contextual validity as well as the reliability and the dimensionality we designed the final version of the questionnaire for employees. We reduced the number of statements for the construct of assertive communication from 9 to 7 , as mentioned above, and for the construct of delegation from 5 to 4 . The statements for the rest of the constructs (empathy, strategic thinking and optimization of work), their components and scales were left unchanged.

\footnotetext{
${ }^{2}$ Nova Kreditna Banka Maribor d.d., Abanka Vipa d.d., Banka Celje d.d., Raiffeisen Banka d.d.
} 


\subsection{Main empirical study}

The main empirical study was based on measurements taken in February and March of 2014; it was a cross-sectional study. We first collected the data via electronic polling on the chosen sample. The collected data was then processed using the following software: (i) IBM SPSS 21.0 (basic analysis, EFA, OLS regression hypotheses testing), (ii) IBM SPSS AMOS 20.0 (CFA) and (iii) Microsoft Excel 2010 (basic analysis). For data processing we predominantly used uni- and multivariate processing methods. The univariate analysis of the data or the descriptive statistical analysis of coaching and employee satisfaction was followed by combining individual components and their factors into constructs. Next, we tested the hypotheses of management coaching model. We tested it using regression analysis on the level of constructs and on the level of their individual components.

We first determined the sample for the study. We decided to include companies with more than 10 employees. Using randomization, the final sample consisted of 2,800 companies: 1,700 small, 745 mid-sized and 355 large companies, according to Slovenian Companies $\mathrm{Act}^{3}$ (ZGD-1). We received 728 responses to our questionnaire. Acquired data was the foundation for testing the main and the secondary hypotheses.

\subsection{Questionnaire for employees}

The data for our study was based on the sample of employees. Designing the questionnaire we designed scales and statements to be able to measure individual coaching constructs. We based our scales and statements on established measuring instruments. We measured the constructs of management coaching using numerous statements linked to five basic constructs.

The first management coaching construct is empathy. Employees graded the following statements based on five-level Likert scale ( 1 - never, 5 - always).

Empathy - 5 statements

1. My superior can manage emotions of others.

2. My superior can defend his point of view; he is a good leader.

3. My superior can influence us, employees, without creating pressure.

4. My superior can recognize his and other people«s emotions.

5. My superior tends to help us, employees.

The second management coaching construct is strategic thinking. It was measured on a five-level Likert scale (1 - never, 5 - always) on the listed statements.

\footnotetext{
${ }^{3}$ OJ of the Republic of Slovenia, Nr. 42/2006.
} 
Strategic thinking -6 statements

1. My superior can present us with the results of a market analysis.

2. My superior can foresee our (employees «) need for different sources of information.

3. My super often comes to independent conclusions.

4. My superior can morph wishes into realistic objectives.

5. My superior can define the necessary stages in workflow.

6. My superior can prepare a business plan.

The third management coaching construct we have measured was assertive communication. The measurement was again based on a five-level Likert scale (1 never, 5 - always) and listed statements.

Assertive communication -7 statements

1. My superior can adjust his way of communication depending on situation.

2. In a conversation, my superior carefully listens to us, employees, and understands what we want to convey.

3. My superior can remain diplomatic even in tense situations.

4. My superior pays attention to nonverbal communication.

5. My superior can say »No« depending on the situation.

6. My superior «s responses are always clear and understandable.

7. My superior does not lobby.

The fourth management coaching construct is delegation. It was measured in the same way as others using the stated statements

Delegation -4 statements

1. My superior delegates tasks evenly.

2. When delegating a task, my superior provides us, employees, with sufficient information.

3. My superior informs us, employees, of changes and novelties in the company.

4. After completing a delegated task, my superior checks its efficiency.

The last construct we included in our measurement instrument was optimization of work. It was measured as the others using the following statements.

Optimization of work -4 statements

1. My superior can simplify work process.

2. My superior can assign responsibility based on our abilities.

3. My superior can correctly select and set up the work tools for us.

4. My superior can correctly select the suitable providers. 
To measure general satisfaction, a one-dimensional variable, we used five-level Likert scale (1- I «m completely dissatisfied, 5 - I $\ll \mathrm{m}$ completely satisfied) on the following key ${ }^{4}$ question:

1. Are you generally satisfied with the work you do?

We then asked another five questions that deal with employee «s perception of personal satisfaction at work; we measured employee satisfaction on the basis of five questions (components). To grade the level of satisfaction we used a five-level Likert scale (1- I $\ll \mathrm{m}$ completely dissatisfied, 5 - I $\ll \mathrm{m}$ completely satisfied). We asked the following questions ${ }^{5}$ :

Are you satisfied with:

1. relationships at workplace (managers and coworkers)?

2. job content?

3. organization of work?

4. the possibility for your creativity in the company?

5. working in a team?

Lastly, we asked for some general information (type of job, seniority, company sector, company size).

In summary, the questionnaire consisted of questions, statements and scales for: (1) coaching activities, (2) general satisfaction, (3) employee satisfaction construct and (4) general characteristics of the company. That way we were able to measure correlations among: (i) coaching constructs and employee satisfaction construct and (ii) coaching constructs and individual components of employee satisfaction. Altogether, the question consisted of 36 questions and statements (including general information questions).

After preliminary study based on the questionnaire, we performed the quantitative (main) study, the results of which we present below.

\footnotetext{
${ }^{4}$ To measure general satisfaction we used an established instrument (Porter \& Steers, 1973; Brayfield \& Rothe, 1951; Camman et al., 1983; Weiss et al., 1967; Smith et al., 1969; Ironson et al., 1989; Taylor \& Bowers, 1974; Quinn \& Shepard, 1974; Schriesheim \& Tsui, 1980; Warr, Cook \& Wall, 1979; Heneman et Schwab, 1985; Spector, 1997; Gounaris, 2006; numerous others)

${ }^{5}$ Already known questions for measuring employee satisfaction (Pogačnik, 1997; Gilmer, 1969; Ristić, 2008; Spector, 1997; Gounaris, 2006; others) were adapted to suit our study.
} 


\section{$4 \quad$ Study results}

\subsection{Final management coaching model}

Fig. 1 presents the management coaching model and the correlations we were testing.

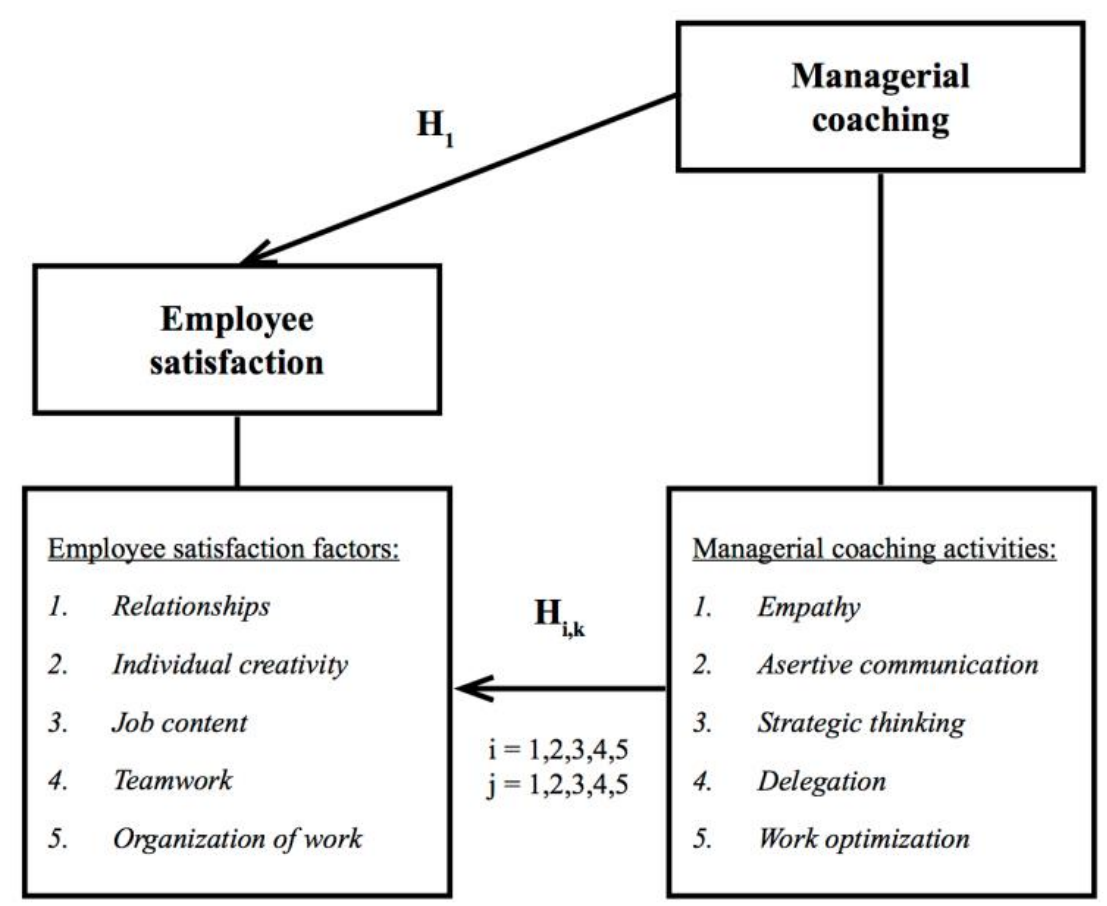

Figure 1: Management coaching model

As stated above and depicted in Fig. 1, we tested the correlations among: (i) the coaching constructs and the employee satisfaction constructs and (ii) coaching constructs and individual components of employee satisfaction.

\subsection{Hypotheses testing results}

Table 1 presents the summary of $\mathrm{t}$ statistics (values of regression coefficients) we used for testing the main and the secondary hypotheses on our sample of employees. 
Table 1: Hypotheses testing results - $t$ statistics - regression coefficients

\begin{tabular}{|c|c|c|c|c|c|c|c|}
\hline hypothesis & $\begin{array}{c}\text { dependent } \\
\text { variable }\end{array}$ & $\begin{array}{c}\text { independent } \\
\text { variable }\end{array}$ & $\begin{array}{c}\text { nonstandard } \\
\text { coefficient B }\end{array}$ & $\begin{array}{c}\text { nonstandard } \\
\text { coefficient } \\
\text { statistical } \\
\text { error }\end{array}$ & $\begin{array}{c}\text { standard } \\
\text { coefficient } \\
\text { B }\end{array}$ & $\mathbf{t}$ & Sig. \\
\hline $\mathrm{H}_{1}$ & $\begin{array}{l}\text { employee } \\
\text { satisfaction }\end{array}$ & $\begin{array}{l}\text { coaching } \\
\text { activities }\end{array}$ & 0,241 & 0,019 & 0,481 & 12,729 & 0,000 \\
\hline $\mathrm{H}_{11}$ & $\begin{array}{l}\text { employee } \\
\text { satisfaction }\end{array}$ & empathy & 0,154 & 0,037 & 0,154 & 4,207 & 0,000 \\
\hline $\mathrm{H}_{21}$ & $\begin{array}{l}\text { employee } \\
\text { satisfaction }\end{array}$ & $\begin{array}{c}\text { asertive } \\
\text { communication }\end{array}$ & 0,820 & 0,021 & 0,820 & 38,572 & 0,000 \\
\hline $\mathrm{H}_{31}$ & $\begin{array}{l}\text { employee } \\
\text { satisfaction }\end{array}$ & $\begin{array}{l}\text { strategic } \\
\text { thinking }\end{array}$ & 0,423 & 0,034 & 0,423 & 12,560 & 0,000 \\
\hline $\mathrm{H}_{41}$ & $\begin{array}{l}\text { employee } \\
\text { satisfaction }\end{array}$ & delegation & 0,842 & 0,020 & 0,842 & 42,083 & 0,000 \\
\hline $\mathrm{H}_{51}$ & $\begin{array}{l}\text { employee } \\
\text { satisfaction }\end{array}$ & $\begin{array}{c}\text { work } \\
\text { optimization }\end{array}$ & 0,876 & 0,018 & 0,876 & 48,830 & 0,000 \\
\hline $\mathrm{H}_{11 \mathrm{a}}$ & relationships & empathy & 0,279 & 0,085 & 0,121 & 3,287 & 0,001 \\
\hline $\mathrm{H}_{12 \mathrm{~b}}$ & $\begin{array}{c}\text { individual } \\
\text { creativity }\end{array}$ & empathy & 0,524 & 0,089 & 0,213 & 5,864 & 0,000 \\
\hline $\mathrm{H}_{13 \mathrm{c}}$ & job content & empathy & 0,263 & 0,091 & 0,107 & 2,905 & 0,004 \\
\hline $\mathrm{H}_{14 \mathrm{~d}}$ & teamwork & empathy & 0,452 & 0,086 & 0,191 & 5,246 & 0,000 \\
\hline $\mathrm{H}_{15 \mathrm{e}}$ & $\begin{array}{c}\text { organization } \\
\text { of work }\end{array}$ & empathy & 0,443 & 0,085 & 0,189 & 5,196 & 0,000 \\
\hline $\mathrm{H}_{21 \mathrm{a}}$ & relationships & $\begin{array}{c}\text { asertive } \\
\text { communication }\end{array}$ & 1,868 & 0,050 & 0,811 & 37,410 & 0,000 \\
\hline $\mathrm{H}_{22 \mathrm{~b}}$ & $\begin{array}{c}\text { individual } \\
\text { creativity }\end{array}$ & $\begin{array}{c}\text { asertive } \\
\text { communication }\end{array}$ & 1,997 & 0,054 & 0,810 & 37,266 & 0,000 \\
\hline $\mathrm{H}_{23 \mathrm{c}}$ & job content & $\begin{array}{c}\text { asertive } \\
\text { communication }\end{array}$ & 1,975 & 0,054 & 0,805 & 36,550 & 0,000 \\
\hline $\mathrm{H}_{24 \mathrm{~d}}$ & teamwork & $\begin{array}{c}\text { asertive } \\
\text { communication }\end{array}$ & 1,933 & 0,051 & 0,817 & 38,135 & 0,000 \\
\hline $\mathrm{H}_{25 \mathrm{e}}$ & $\begin{array}{l}\text { organization } \\
\text { of work }\end{array}$ & $\begin{array}{c}\text { asertive } \\
\text { communication }\end{array}$ & 1,877 & 0,052 & 0,803 & 36,310 & 0,000 \\
\hline $\mathrm{H}_{31 \mathrm{a}}$ & relationships & $\begin{array}{l}\text { strategic } \\
\text { thinking }\end{array}$ & 0,928 & 0,078 & 0,403 & 11,859 & 0,000 \\
\hline $\mathrm{H}_{32 b}$ & $\begin{array}{l}\text { individual } \\
\text { creativity }\end{array}$ & $\begin{array}{l}\text { strategic } \\
\text { thinking }\end{array}$ & 0,975 & 0,084 & 0,396 & 11,615 & 0,000 \\
\hline $\mathrm{H}_{33 \mathrm{c}}$ & job content & $\begin{array}{l}\text { strategic } \\
\text { thinking }\end{array}$ & 0,956 & 0,084 & 0,390 & 11,401 & 0,000 \\
\hline $\mathrm{H}_{34 \mathrm{~d}}$ & teamwork & $\begin{array}{l}\text { strategic } \\
\text { thinking }\end{array}$ & 1,009 & 0,079 & 0,426 & 12,697 & 0,000 \\
\hline $\mathrm{H}_{35 \mathrm{e}}$ & $\begin{array}{c}\text { organization } \\
\text { of work }\end{array}$ & $\begin{array}{l}\text { strategic } \\
\text { thinking }\end{array}$ & 1,050 & 0,078 & 0,449 & 13,543 & 0,000 \\
\hline $\mathrm{H}_{41 \mathrm{a}}$ & relationships & delegation & 1,898 & 0,048 & 0,825 & 39,261 & 0,000 \\
\hline $\mathrm{H}_{42 \mathrm{~b}}$ & $\begin{array}{l}\text { individual } \\
\text { creativity }\end{array}$ & delegation & 2,023 & 0,052 & 0,821 & 38,768 & 0,000 \\
\hline $\mathrm{H}_{43 \mathrm{c}}$ & job content & delegation & 2,030 & 0,051 & 0,828 & 39,720 & 0,000 \\
\hline $\mathrm{H}_{44 \mathrm{~d}}$ & teamwork & delegation & 1,987 & 0,048 & 0,839 & 41,623 & 0,000 \\
\hline $\mathrm{H}_{45 \mathrm{e}}$ & $\begin{array}{l}\text { organization } \\
\text { of work }\end{array}$ & delegation & 1,947 & 0,048 & 0,833 & 40,563 & 0,000 \\
\hline $\mathrm{H}_{51 \mathrm{a}}$ & relationships & $\begin{array}{c}\text { optimization of } \\
\text { work }\end{array}$ & 1,991 & 0,043 & 0,865 & 46,433 & 0,000 \\
\hline $\mathrm{H}_{52 \mathrm{~b}}$ & $\begin{array}{l}\text { individual } \\
\text { creativity }\end{array}$ & $\begin{array}{c}\text { optimization of } \\
\text { work }\end{array}$ & 2,119 & 0,047 & 0,860 & 45,428 & 0,000 \\
\hline $\mathrm{H}_{53 \mathrm{c}}$ & job content & $\begin{array}{c}\text { optimization of } \\
\text { work }\end{array}$ & 2,127 & 0,045 & 0,867 & 46,894 & 0,000 \\
\hline $\mathrm{H}_{54 \mathrm{~d}}$ & teamwork & $\begin{array}{c}\text { optimization of } \\
\text { work }\end{array}$ & 2,072 & 0,043 & 0,875 & 48,734 & 0,000 \\
\hline $\mathrm{H}_{55 \mathrm{e}}$ & $\begin{array}{l}\text { organization } \\
\text { of work }\end{array}$ & $\begin{array}{c}\text { optimization of } \\
\text { work }\end{array}$ & 1,985 & 0,046 & 0,849 & 43,299 & 0,000 \\
\hline
\end{tabular}


Below we summarize the results of testing of the main and the secondary hypotheses. We present regression analysis findings.

Table 2: The results of the main and the secondary hypotheses testing - sample of employees

\begin{tabular}{|c|c|c|}
\hline & POSED HYPOTHESIS & FINDINGS \\
\hline $\mathbf{H}_{1}$ & $\begin{array}{l}\text { Implementing management coaching model positively influences } \\
\text { employee satisfaction. }\end{array}$ & confirmed \\
\hline $\mathbf{H}_{11}$ & Empathy positively influences employee satisfaction. & confirmed \\
\hline $\mathbf{H}_{21}$ & Assertive communication positively influences employee satisfaction. & confirmed \\
\hline $\mathbf{H}_{31}$ & Strategic thinking positively influences employee satisfaction. & confirmed \\
\hline $\mathbf{H}_{41}$ & Delegation positively influences employee satisfaction. & confirmed \\
\hline $\mathbf{H}_{51}$ & Work optimization positively influences employee satisfaction. & confirmed \\
\hline $\mathbf{H}_{11 \mathbf{a}}$ & Empathy positively influences relationships. & confirmed \\
\hline $\mathbf{H}_{12 \mathrm{~b}}$ & Empathy positively influences individual creativity. & confirmed \\
\hline $\mathbf{H}_{13 \mathrm{c}}$ & Empathy positively influences job content. & confirmed \\
\hline $\mathbf{H}_{14 \mathrm{~d}}$ & Empathy positively influences teamwork. & confirmed \\
\hline $\mathbf{H}_{15 \mathrm{e}}$ & Empathy positively influences organization of work. & confirmed \\
\hline $\mathbf{H}_{21 \mathbf{a}}$ & Assertive communication positively influences relationships. & confirmed \\
\hline $\mathbf{H}_{22 \mathrm{~b}}$ & Assertive communication positively influences individual creativity. & confirmed \\
\hline $\mathbf{H}_{23 \mathrm{c}}$ & Assertive communication positively influences job content. & confirmed \\
\hline $\mathbf{H}_{24 \mathrm{~d}}$ & Assertive communication positively influences teamwork. & confirmed \\
\hline $\mathbf{H}_{25 \mathrm{e}}$ & Assertive communication positively influences organization of work. & confirmed \\
\hline $\mathbf{H}_{31 \mathbf{a}}$ & Strategic thinking positively influences relationships. & confirmed \\
\hline $\mathbf{H}_{32 \mathrm{~b}}$ & Strategic thinking positively influences individual creativity. & confirmed \\
\hline $\mathbf{H}_{33 \mathrm{c}}$ & Strategic thinking positively influences job content. & confirmed \\
\hline $\mathbf{H}_{34 \mathrm{~d}}$ & Strategic thinking positively influences teamwork. & confirmed \\
\hline $\mathbf{H}_{35 \mathrm{e}}$ & Strategic thinking positively influences organization of work. & confirmed \\
\hline $\mathbf{H}_{41 \mathbf{a}}$ & Delegation positively influences relationships. & confirmed \\
\hline $\mathbf{H}_{42 \mathrm{~b}}$ & Delegation positively influences individual creativity. & confirmed \\
\hline $\mathbf{H}_{43 \mathrm{c}}$ & Delegation positively influences job content. & confirmed \\
\hline $\mathbf{H}_{44 \mathrm{~d}}$ & Delegation positively influences teamwork. & confirmed \\
\hline $\mathbf{H}_{45 \mathrm{e}}$ & Delegation positively influences organization of work. & confirmed \\
\hline $\mathbf{H}_{51 \mathbf{a}}$ & Work optimization positively influences relationships. & confirmed \\
\hline $\mathbf{H}_{52 \mathrm{~b}}$ & Work optimization positively influences individual creativity. & confirmed \\
\hline $\mathbf{H}_{53 \mathrm{c}}$ & Work optimization positively influences job content. & confirmed \\
\hline $\mathbf{H}_{54 \mathrm{~d}}$ & Work optimization positively influences teamwork. & confirmed \\
\hline $\mathbf{H}_{55 \mathrm{e}}$ & Work optimization positively influences organization of work. & confirmed \\
\hline
\end{tabular}

Table 2 shows we have confirmed $\mathrm{H}_{1}$, which means we have confirmed the correlation among individual coaching constructs and the employee satisfaction construct. Confirming hypotheses $\mathrm{H}_{11}$ through $\mathrm{H}_{51}$ means that correlations among individual coaching constructs are appropriate and possible. Having confirmed all of the secondary hypotheses $\mathrm{H}_{11 \text { a }}$ through $\mathrm{H}_{55}$ e, we confirmed the correlations among the coaching constructs and individual components of employee satisfaction. 
$146 \mid$\begin{tabular}{l|l} 
LEXONOMICA \\
P. Cajnko \& S. Kraljić: Management Coaching Model and Impact of its Activities on Employee \\
Satisfaction
\end{tabular}

\section{$5 \quad$ Conclusion}

The results of our study helped us make the following conclusions: (1) Management coaching is a multilayered construct. To measure the management coaching activities, we use the following constructs: (i) empathy, (ii) assertive communication, (iii) strategic thinking, (iv) delegation and (v) optimization of work. To measure the individual construct we use the appropriate scales. (2) Implementing management coaching model positively influences employee satisfaction construct, because coaching constructs exert an influence on employee satisfaction construct. (3) Employee satisfaction is multi-factorial construct that is defined by the following variables or components: (i) job content, (ii) individual creativity, (iii) work organization, (iv) teamwork and (v) relationships. (4) We determined that all of the coaching constructs (empathy, assertive communication, strategic thinking, delegation and optimization of work) positively influence all of the employee satisfaction components (job content, individual creativity, work organization, teamwork and relationships).

To sum up, the key foundation of the research are constituted statistical methods, with the help of which we collected and analyzed the data collected in the field survey. The advantage of the use of selected statistical methods is in the underlying conceptual management coaching model and the impact of its activities on employee satisfaction, which represents the developed instrument for coaching and employee satisfaction.

In this context we must draw attention to one limitation/disadvantage. The results of the analysis show that the reliability of the construct empathy (a construct in the context of the coaching) as a whole is relatively poor, but still the construct empathy is valid. Further development and improvement of the measurement scales and the use of the instrument or further analysis with a view to improving reliability is one of the options to upgrade our research.

The discussed topic is or practical importance. The study«s results will help managers, Slovenian as well as foreign, understand the influence of coaching activities on employee satisfaction. Also, employees and individuals will be able to familiarize themselves with a number of methods and models that help individuals understand coaching activities and with that help them gain a higher level of general and workplace satisfaction.

We expect that the study«s results will help companies, in Slovenia and abroad, to enrich their abilities and increase their performance.

Implementing coaching activities in a company represents one of the possibilities for emergence from the crisis the economy is in at the moment. Manager who is a coach can be socially responsible toward his employees, the company and the society in general as well as the environment; that is a basis for existence of countries and the world. 
Various authors have studied coaching, its characteristics, activities and certain models and tools, and its influence on productivity, but to our knowledge nobody has studied the interesting influence of management coaching activities on employee satisfaction. That is why we centered our research on the question: What is the potential additive effect of implementing management coaching model and its activities on employee satisfaction? We have designed management coaching model that is based on coaching activities as possible factor of employee satisfaction. In the future we will start the process to make our model recognized. We also might upgrade the existing model, which is one of the challenges for future studies. We also see opportunities in improving and more thoroughly testing the characteristics of our measurement instrument, its upgrading, improving the measuring scales, repeating the measurement on different samples (we focused on companies in service industry) and linking our constructs with other constructs to ensure comprehensiveness our successfulness criteria.

\section{References}

Brayfield, A. H. and Rothe, H. F. (1951) An index of job satisfaction. Journal of Applied Psychology, 35, pp. 307-311.

Cahill, J. D. (1996) International Marketing: Your company's next stage of growth (New York, London: The Haworth Press).

Cajnko, P. (2014) Managementski model svetovalnega mentorstva in vpliv njegovih aktivnosti na zadovoljstvo zaposlenih in uspešnost podjetja. Doktorska disertacija. Maribor: Ekonomsko poslovna fakulteta Univerze v Mariboru.

Camman, C., Fichman, M., Jenkins, jr., D. and Flesh, J.R. (1983) Assessing the attitudes and perceptions of organizational members. V S.E. Seashore, Lawler, E., Mirvins, P.H. in Cammann, C. Assessing organizational change, pp. 71-138 (New York: John Wiley \& Sons).

Cornelius, E. T. in Hakel, M. D. (1978) Job Element Inventory. Zapis v podatkovni zbirki. Retrieved on 18.11.2013 from: PsycTESTS. doi: 10.1037/t10252-000.

Čeč, F. (2006) S coachingom do večjih poslovnih in osebnih dosežkov (Zagorje ob Savi: Regionalni center za razvoj).

Dattner, B. (2014) How to Participate in Your Employee's Coaching. In Harvard Business Review. Retrieved on 4.2.2015 from: https://hbr.org/2014/11/how-to-participate-inyour-employees-coaching

Desmarais, M. (2005) Contact Center Employee satisfaction \& Customer Satisfaction Link (Milwaukee: Manpower).

George, M. J. and Jones, R. G. (1996) Understanding and Managing Organizational Behavior (Addison: Wesley Publishing Company).

Goffee, R. (2006) Follow the Leader. Coaching at Work. Retrieved on 18.9.2013 from: http://www.cipd.co.uk/coachingatwork/articles/Follow+the+leader.htm

Gounaris, S. P. (2006) Internal-market orientation and its measurement. Journal of Business Research, 59, pp. 432-448.

Hall, L. (2006) Tailoring Your Approach. Coaching at Work. Retrieved on 18.9.2013 from:http://www.cipd.co.uk/coachingatwork/articles/Tailoring+your+approach.htm

Hollenbeck, J. and Wright, P. (1994) Human Resource Management (Irwin: Austen Press).

Jarvis, J. (2006) The Rise and Rise of Coaching, Coaching at Work,1(3), str. 26-27

Lawler, E. E. (1994) Motivation in work organizations (San Francisco: Jossey - Bass Publishers).

Leshinsky, M. (2007) Coaching Millions (New York: Lifestyle Enterpreneur Press). 
Megginson, D. and Clutterbuck, D. (2007) Techniques for Coaching and Mentoring. (Oxford: Butterworth-Heinemann).

Mihalič, R. (2006) Management človeškega kapitala (Škofja Loka: Mihalič in Partnerji).

Možina, S. (2002) Učeča se organizacija - učeči se management. V Management - nova znanja za uspeh (pp. 12-45) (Radovljica: Didakta).

Oakley, J. (2004) Linking Organizational Characteristics to Employee Attitudes and Behavior (Illinois: Northwestern University Research Center).

Oswald, A. J. and Clark, A. E. (1996) Satisfaction and Comparison Income, Jurnal of Public Economics, 61, pp. 359-381.

Pohlmann, C. (1999) Study on Workplace Satisfaction in Private, Public Sectors (Toronto: Goldfarb Consultants).

Porter, L. W. and Steers, R. W. (1973) Organizational, Work and Personal Factors in Employee Turnover and Absenteeism, Psychological Bulletin 80, pp. 151-176.

Slovenian Human Resource Association (2014) Uspešna konferenca o zavzetosti zaposlenih. Retrived on 3.2.2015 from: http://www.skz.si/uspesna-konferenca-o-zavzetostizaposlenih/

Skiffington, S. and Zeus, P. (2003) The Comlete Guide to Coaching at Work (Sydney: McGraw-Hill Companies).

Stemberger, P. J. (2008) Coaching v poslovnem okolju. Retrieved on 6.8.2013 from:http://www.inti.si/images/stories/Vseved/coaching/5_coaching_v_poslovnem_o kolju.pdf

Stokes, P. (2008) Just Doing My Job. Coaching at Work 3, p. 58.

Škerlavaj, M. et al. (2007) Organizational learning culture - the missing link between business process change and organizational performance, International Journal of Production Economics, 106 (2), pp. 346-367.

Whitworth, L., Kimsey- House, K., Kimsey- House, H. and Sandahl, P. (2011) Coactive Coaching (Mountain View: Davies-Black Publishing).

Weiss, D. J., Dawis, R. V., England, G. W. and Lofquist, L. H. (1967) Manual for the Minnesota Satisfaciton Questionnaire (Minneapolis: Industrial Relations Center: University of Minnesota). 